\title{
A Chimeric Receptor/Oncogene That Can Be Regulated by a Ligand In Vitro and In Vivo
}

\author{
K. Okuda, ${ }^{\star}$ A. D’Andrea, ${ }^{\ddagger}$ R.A. Van Etten, ${ }^{\S}$ and J.D. Griffin* \\ $*$ Division of Hematologic Malignancies and ${ }^{\ddagger}$ Division of Pediatric Oncology, Dana-Farber Cancer Institute, Boston, Massachusetts \\ 02115; and ${ }^{\S}$ Center for Blood Research, and Harvard Medical School, Boston, Massachusetts 02115
}

\begin{abstract}
The $B C R / A B L$ oncogene encodes an activated tyrosine kinase that causes human chronic myelogenous leukemia. The mechanism of transformation, however, is complex and not well understood. One of the important contributions of BCR to transformation is believed to be dimerization or oligomerization of $\mathrm{ABL}$, thereby activating $\mathrm{ABL}$ tyrosine kinase activity. We reasoned that if $\mathrm{ABL}$ was dimerized through other mechanisms, activation of the tyrosine kinase activity should also result, and the activated kinase may also be transforming. Erythropoietin is known to activate its receptor by causing dimerization, and therefore a synthetic oncogene was created by linking the extracytoplasmic and transmembrane domains of the EPO receptor with c-ABL. This chimeric receptor was stably expressed in $\mathrm{Ba} / \mathrm{F} 3$ cells and, in the absence of EPO, had no detectable biological effect on the cells. EPO, however, induced a rapid, dose-dependent activation of ABL tyrosine kinase activity and phosphorylation of several cellular proteins. The major target proteins have been identified, and are very similar to the known substrates of BCR/ABL, including Shc, CBL, CRKL, and several proteins in the cytoskeleton. EPO treatment also resulted in biological effects that were remarkably similar to those of $\mathrm{BCR} / \mathrm{ABL}$, including improved viability, altered integrin function, and a weak mitogenic signal. The biological effects were in part dose-dependent, in that low EPO concentrations enhanced viability but did not cause proliferation. At high EPO doses, kinase activation was maximal, and a mitogenic effect was also revealed. In nude mice, $\mathrm{Ba} / \mathrm{F} 3$ cells expressing this chimeric receptor did not cause detectable disease without administration of pharmacologic doses of EPO. If EPO was given intraperitoneally 5 days a week, however, a dose-dependent lethal leukemia resulted. This ligand-regulatable oncogene mimics some of the biological effects of $\mathrm{BCR} / \mathrm{ABL}$, and analysis of $\mathrm{ABL}$ mutants in this system will be useful to dissect the signaling pathways that cause CML. (J. Clin. Invest. 1997. 100: 1708-1715.) Key words: chronic myelogenous leukemia • $\mathrm{BCR} / \mathrm{ABL} \cdot$ oncogene $\cdot$ erythropoietin
\end{abstract}

Address correspondence to James D. Griffin, M.D., Division of Hematologic Malignancies, Dana-Farber Cancer Institute and Harvard Medical School, 44 Binney Street, Boston, MA 02115. Phone: 617632-3360; FAX: 617-632-4388; E-mail: james_griffin@dfci.harvard.edu

Received for publication 13 March 1997 and accepted in revised form 7 August 1997.

J. Clin. Invest.

(C) The American Society for Clinical Investigation, Inc. 0021-9738/97/10/1708/08 \$2.00

Volume 100, Number 7, October 1997, 1708-1715

http://www.jci.org

\section{Introduction}

The $B C R / A B L$ oncogene is formed by a reciprocal translocation between chromosomes 9 and 22 that fuses the $\mathrm{NH}_{2}$-terminal portion of the BCR gene upstream of the c-ABL tyrosine kinase gene (1-7). The resulting fusion oncoprotein, p210BCR/ABL, has increased tyrosine kinase activity, and relocates to the cytoskeleton where it is responsible for phosphorylating a number of cellular proteins and causing chronic myelogenous leukemia (8-12). Activation of the ABL tyrosine kinase is caused by an $\mathrm{NH}_{2}$-terminal segment of BCR contained within amino acids 1-64, which is believed to induce the formation of oligomers (10). Deletion of this $\mathrm{NH}_{2}$-terminal segment reduces BCR/ABL kinase activity, and also reduces transforming activity (10). The notion that oligomerization of $\mathrm{ABL}$ is important for kinase activation is further supported by the finding of rare cases of human leukemia in which c-ABL is fused to TEL, an ets-family member, instead of BCR. TEL contains a helix-loop-helix motif that may also oligomerize, thereby activating ABL kinase (13-15).

The above observations suggest that oligomerization of ABL is likely to activate and deregulate ABL's tyrosine kinase activity $(15,16)$. We decided to test this hypothesis directly by constructing a synthetic oncogene in which oligomerization (dimerization) could be controlled by an exogenous ligand. Several members of the hematopoietic cytokine family such as growth hormone, erythropoietin, granulocyte colony-stimulating factor, and thrombopoietin, are believed to activate their receptors by inducing dimerization or oligomerization (17). A chimeric receptor was constructed by fusing the extracellular ligand-binding domain of the erythropoietin receptor (EPO $\mathrm{R})^{1}$ to $\mathrm{c}-\mathrm{ABL}$. A cDNA encoding this structure was expressed in a nonleukemic, factor-dependent, murine hematopoietic cell line, $\mathrm{Ba} / \mathrm{F} 3$, and the biochemical and biological activities of this molecule were examined. In the absence of EPO, the EPO $\mathrm{R} / \mathrm{ABL}$ molecule had negligible intrinsic tyrosine kinase activity, and did not promote either cell viability or proliferation. EPO, however, induced a rapid, dose-dependent increase in tyrosine phosphorylation of the chimeric receptor itself, and also induced phosphorylation of several other cellular proteins already known to be substrates for the BCR/ABL tyrosine kinase, such as Shc and CBL (18-20). In the Ba/F3 cells, EPO also caused a dose-dependent increase in viability and, at high doses, proliferation. In nude mice, $\mathrm{Ba} / \mathrm{F} 3$ cells expressing EPO $\mathrm{R} / \mathrm{ABL}$ caused a lethal leukemia if EPO was administered, but did not cause detectable disease in the absence of EPO administration. Thus, this chimeric receptor is a prototype of an oncogene that can be rapidly regulated both in vitro and in vivo.

1. Abbreviation used in this paper: EPO R, erythropoietin receptor. 


\section{Methods}

$E P O R / A B L$ chimeric receptor. A cDNA encoding the ligand-binding domain of the EPO receptor fused to $\mathrm{c}-\mathrm{ABL}$ was generated by PCR using the cDNAs for the murine EPO receptor and murine c-ABL as templates $(21,22)$. The EPO R/ABL junction was made at tryptophan residue 282 of the EPO receptor, and at methionine residue 1 of c-ABL. The resulting protein contains the transmembrane domain of the EPO receptor and 11 additional intracellular amino acids of the EPO R, followed by c-ABL. Previous studies have shown that an EPO receptor truncated at tryptophan 282 is nonfunctional and cannot activate known signaling pathways (23). The PCR product was ligated into the expression vector $\mathrm{pPL}$ and transfected into $\mathrm{Ba} / \mathrm{F} 3$ cells as described below.

Cells and cell culture. Ba/F3 cells were maintained in RPMI 1640 medium supplemented with $10 \%$ FCS and $10 \%$ conditioned medium from WEHI-3B cells as a source of murine IL-3 at $37^{\circ} \mathrm{C}$. The parental $\mathrm{Ba} / \mathrm{F} 3$ cells used in these experiments do not express detectable endogenous EPO receptors, nor do they proliferate in response to EPO. As a control, $\mathrm{Ba} / \mathrm{F} 3$ cells transfected with a wild-type murine EPO receptor were used (23), and these cells were shown to proliferate in response to exogenous EPO. Plasmids pPL EPO R/ABL and pGD, which contains a neomycin resistance gene, were cotransfected into $\mathrm{Ba} / \mathrm{F} 3$ cells at a 20:1 molar ratio, respectively, using electroporation with a Gene Pulsar ${ }^{\mathrm{TM}}$ (Bio-Rad Laboratories, Richmond, CA) as described previously (16). Selection with G418 $(1 \mathrm{mg} / \mathrm{ml})$ in RPMI 1640 medium containing $10 \%$ WEHI conditioned medium was initiated $48 \mathrm{~h}$ after electroporation. A polyclonal cell line, termed EPO R/ABL $\mathrm{Ba} / \mathrm{F} 3$ cells, was selected for further analysis. $\mathrm{Ba} / \mathrm{F} 3$ cells transformed by either $\mathrm{p} 210 \mathrm{BCR} / \mathrm{ABL}$ or $\mathrm{p} 190 \mathrm{BCR} / \mathrm{ABL}$ have been described previously (16).

Flow cytometric analysis of EPO receptor expression. $\mathrm{Ba} / \mathrm{F} 3$ cells and their subclones were washed and resuspended in RPMI 1640 medium. Cells $\left(1.0 \times 10^{6}\right)$ were incubated with a saturating concentration of a protein A-purified polyclonal antiserum directed against the extracytoplasmic domain of human EPO R in a 1:200 dilution in a total volume of $200 \mu \mathrm{l}$ (24). The cells were washed with PBS and stained with an FITC-conjugated anti-rabbit second antibody. The cells were analyzed with an Epics V flow cytometer (Coulter Immunology, Hialeah, FL). Nonimmune rabbit serum was used as negative control.

Immunoblotting and immunoprecipitation. Cells were deprived of growth factors by culturing in medium containing $10 \%$ FCS in RPMI 1640 overnight, and were then stimulated with either human recombinant EPO (Amgen Inc., Thousand Oaks, CA) or murine recombinant IL-3 (Upstate Biotechnology Inc., Lake Placid, NY) as indicated in each experiment. The cells were lysed in $1 \%$ Nonidet P40, $137 \mathrm{mM} \mathrm{NaCl}, 1 \mathrm{mM} \mathrm{MgCl}$, $10 \%$ glycerol, $20 \mathrm{mM}$ Tris, $\mathrm{pH} 8.0,1 \mathrm{mM}$ phenylmethyl-sulfonylfluoride, $20 \mu \mathrm{g} / \mathrm{ml}$ aprotinin, $1 \mathrm{mM}$ Na orthovanadate, and $10 \mathrm{ng} / \mathrm{ml}$ leupeptin at $1 \times 10^{8}$ cells $/ \mathrm{ml}$. Immunoprecipitation was performed from lysates with $50 \mu$ l Protein A Sepharose beads (Pharmacia Fine Chemicals, Uppsala, Sweden) after incubation with specific antibodies. Protein samples were separated under reducing conditions by SDS polyacrylamide gel electrophoresis (6$12 \%$ polyacrylamide gradients), and electrophoretically transferred to PVDF membranes (Millipore Corp., Bedford, MA). For immunoblotting, membranes were blocked in TBS (10 mM Tris, $\mathrm{pH} 8.0,150$ $\mathrm{mM} \mathrm{NaCl}$ ) containing $5 \%$ dry milk for $1 \mathrm{~h}$, then incubated with the appropriate primary antibodies in TBST overnight at $4^{\circ} \mathrm{C}$. Primary antibodies were detected with a horseradish peroxidase-conjugated secondary antibody at a 1:5,000 dilution and were later developed by a chemiluminescent reaction and exposed to radiographic film.

Antibodies. Antiphosphotyrosine monoclonal antibody (4G10) was provided by Dr. Brian Drucker (University of Oregon Health Sciences Center, Portland, OR) (25). Anti-ABL, -SHP2, and -CBL antibodies were purchased from Santa Cruz Biotechnology, Inc. (Santa Cruz, CA). Anti-Shc antibody was purchased from Transduction Laboratories Inc. (Lexington, KY), and anti-rasGAP antibody was purchased from Upstate Biotechnology Inc. (Lake Placid, NY). An antiphospho STAT polyclonal antibody that recognizes only tyrosine phosphorylated STAT 1 and 5 was provided by Dr. David Frank (Dana-Farber Cancer Institute) (26).

Fibronectin adhesion assay. Soluble human fibronectin (GIBCOBRL, Gaithersburg, MD) was coated onto 24-well plates (Becton Dickinson Labware, Lincoln Park, NJ) at a $10 \mu \mathrm{g} / \mathrm{ml}$ concentration, and was incubated overnight at $4^{\circ} \mathrm{C}$. Control wells were coated with BSA, also at $10 \mu \mathrm{g} / \mathrm{ml}$. $10^{6}$ cells were added to each well, and were

\section{$\mathrm{Ba} / \mathrm{F} 3$ Cells \\ $\mathrm{Ba} / \mathrm{F} 3$ Cells \\ Ba/F3 Epo R/Abl Cells \\ Control Antibody \\ Anti-Epo Receptor \\ Anti-Epo Receptor}

A

\begin{tabular}{|c|c|c|c|}
\hline $\begin{array}{l}\text { NEG: } \\
x \\
M\end{array}$ & $\begin{array}{r}2 \cdot 40 \\
37 \cdot 48\end{array}$ & $\begin{array}{ll}\text { BAF } & \\
\text { x } & 4.10 \\
M & 34.65\end{array}$ & $\begin{array}{l}E-A \\
\text { 否 }\end{array}$ \\
\hline
\end{tabular}

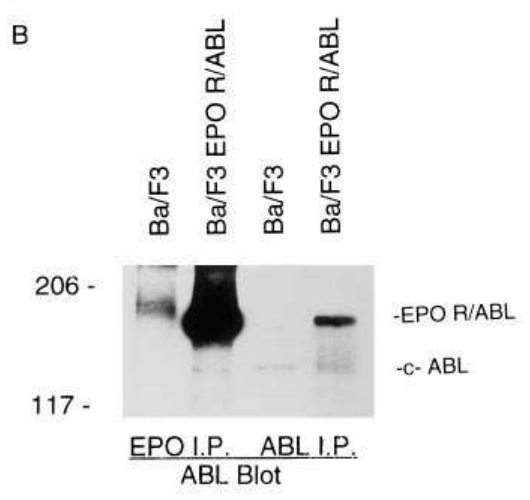

Figure 1. Expression of EPO $\mathrm{R} / \mathrm{ABL}$ chimeric protein in transfected $\mathrm{Ba} / \mathrm{F} 3$ cells. Successful transfection was confirmed by both immunophenotyping $(A)$ and immunoblotting $(B)$. EPO receptor (EPO R) surface expression was detected using anti-EPO R antibody and FITC-conjugated second antibody for FACS analysis. Expression of a chimeric molecule was confirmed by immunoblotting with anti-ABL antibody after immunoprecipitation with either anti-ABL or anti-EPO receptor antibody. $(C)$ Model of the EPO R/ABL chimeric molecule. 


\section{$E P O=\quad \begin{array}{lllllll}0 & .05 & 0.1 & 0.5 & 1 & 2 & \text { Units } / \mathrm{ml}\end{array}$}

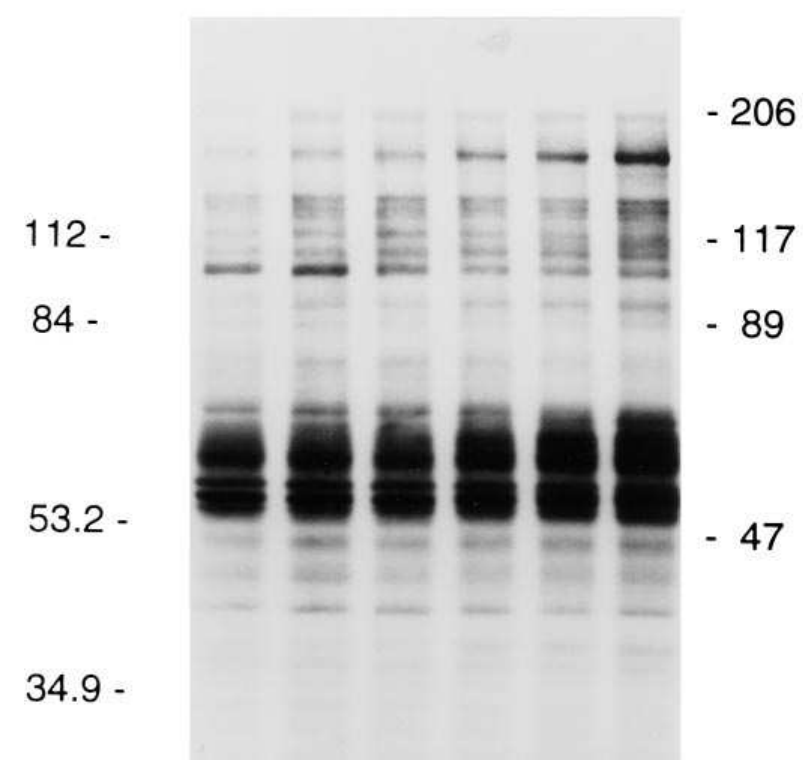

Figure 2. Dose-response of EPO-induced protein tyrosine phosphorylation in EPO R/ABL transfected $\mathrm{Ba} / \mathrm{F} 3$ cell line. Cells were factordeprived overnight and then stimulated for $15 \mathrm{~min}$ with $0-2 \mathrm{U} / \mathrm{ml}$ EPO. Proteins were separated in a SDS-polyacrylamide gel, and changes in protein tyrosine phosphorylation were detected by immunoblotting with a monoclonal antiphosphotyrosine antibody (4G10). Molecular wt markers are as indicated.

cultured in the presence or absence of IL-3 or EPO as indicated for $16 \mathrm{~h}$ at $37^{\circ} \mathrm{C}, 5 \% \mathrm{CO}_{2}$. The plates were washed gently with PBS several times, and then cells attached to the plates were detected by Wright-Giemsa cell staining.

Tritiated thymidine assay. $\left[{ }^{3} \mathrm{H}\right]$ thymidine incorporation was mea- sured after incubating cultures with $0.2 \mathrm{mCi}$ of $\left[{ }^{3} \mathrm{H}\right]$ thymidine $(2 \mathrm{Ci} /$ $\mathrm{mmol} ; 1 \mathrm{Ci}=37 \mathrm{GBq}$; New England Nuclear, Boston, MA) for $8 \mathrm{~h}$.

Animal studies. 7-9-wk-old NCr nu/nu mice (Taconic Farms Inc., Germantown, NY) were maintained in bioclean conditions. All experiments included three to six animals in each group, and all experiments were repeated at least once. All experiments involving animals were reviewed and approved by the Dana-Farber Cancer Institute Animal Care and Use Committee. Ba/F3, Ba/F3 BCR/ABL, and Ba/ F3 EPO R/ABL cells were injected intravenously in a small volume $(<500 \mu \mathrm{l})$ in a tail vein. Mice were then given either PBS or human EPO by intraperitoneal injection 5 times/wk.

\section{Results}

EPO induces tyrosine phosphorylation of EPO R/ABL and several other cellular proteins in cell lines expressing EPO $R / A B L$. The IL-3-dependent $\mathrm{Ba} / \mathrm{F} 3$ cell line was transfected with an EPO R/ABL cDNA in an expression vector as described in Methods. The expression of the chimeric receptor in a polyclonal subline was confirmed by both immunofluorescent cell staining with an anti-EPO receptor antibody and immunoblotting with an anti-ABL antibody (Fig. 1). Interestingly, c-Abl is also precipitated by anti-EPO $\mathrm{R}$ monoclonal antibody in cells expressing EPO R/ABL, suggesting that c-ABL interacts with this chimeric receptor in $\mathrm{Ba} / \mathrm{F} 3$ cells (Fig. 1). In the EPO R/ABL cells, EPO induced a dose-dependent increase in protein tyrosine phosphorylation. One of the most prominently phosphorylated proteins after EPO treatment comigrated with EPO R/ABL receptor, which is presumed to be tyrosine phosphorylated in response to dimerization induced by EPO (Fig. 2). This tyrosine phosphoprotein comigrated with the receptor band that was immunoprecipitated.

Using a dose of EPO of $2 \mathrm{U} / \mathrm{ml}$, the time course of ABL kinase activation was examined (Fig. 3). The chimeric receptor protein was phosphorylated on tyrosine residues within 5 min of EPO treatment, and the phosphorylation persisted for longer than $60 \mathrm{~min}$. EPO also induced tyrosine phosphorylation of other cellular proteins of 140, 120, 68, and $39 \mathrm{kD}$. EPO

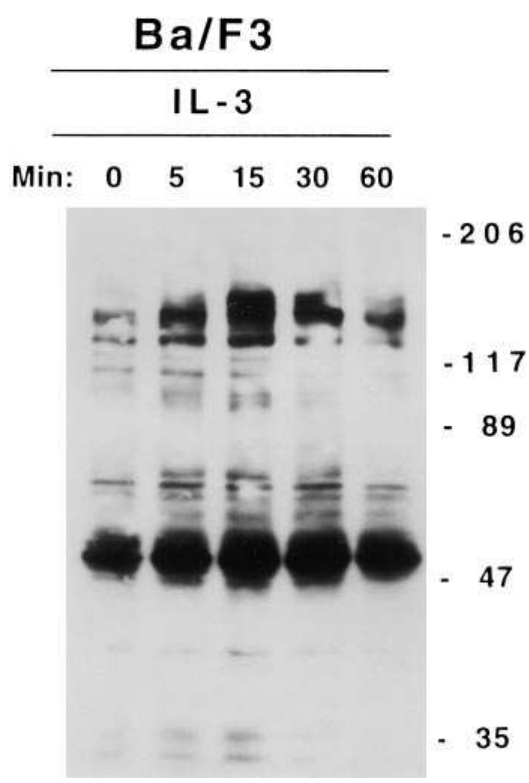

\section{Ba/F3-EPOR/ABL}

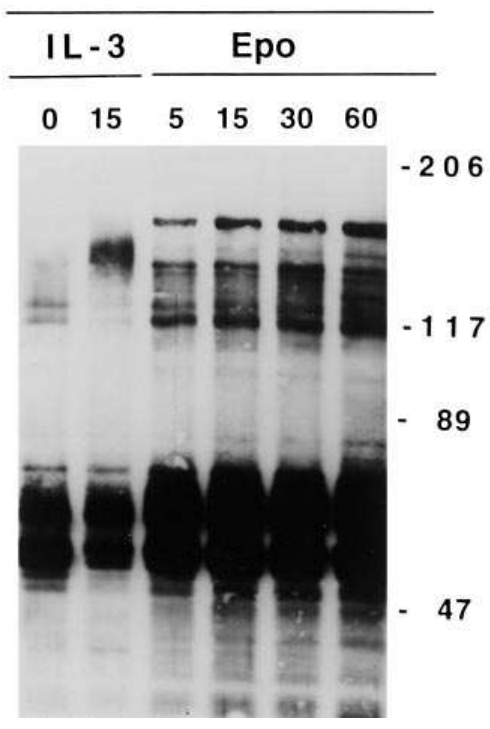

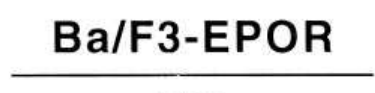

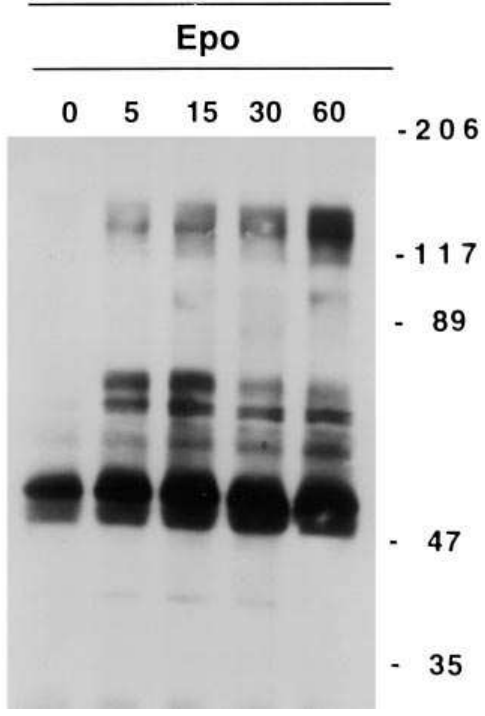

Figure 3. Time course of ABL kinase activation in EPO R/ABL transfected Ba/F3 cell line. The indicated cell lines were stimulated either with IL-3 (1 ng/ml) or EPO (2 U/ml) for 0-60 min. Proteins phosphorylated on tyrosine were visualized by antiphosphotyrosine immunoblotting. 


\section{Ba/F3 Cells}

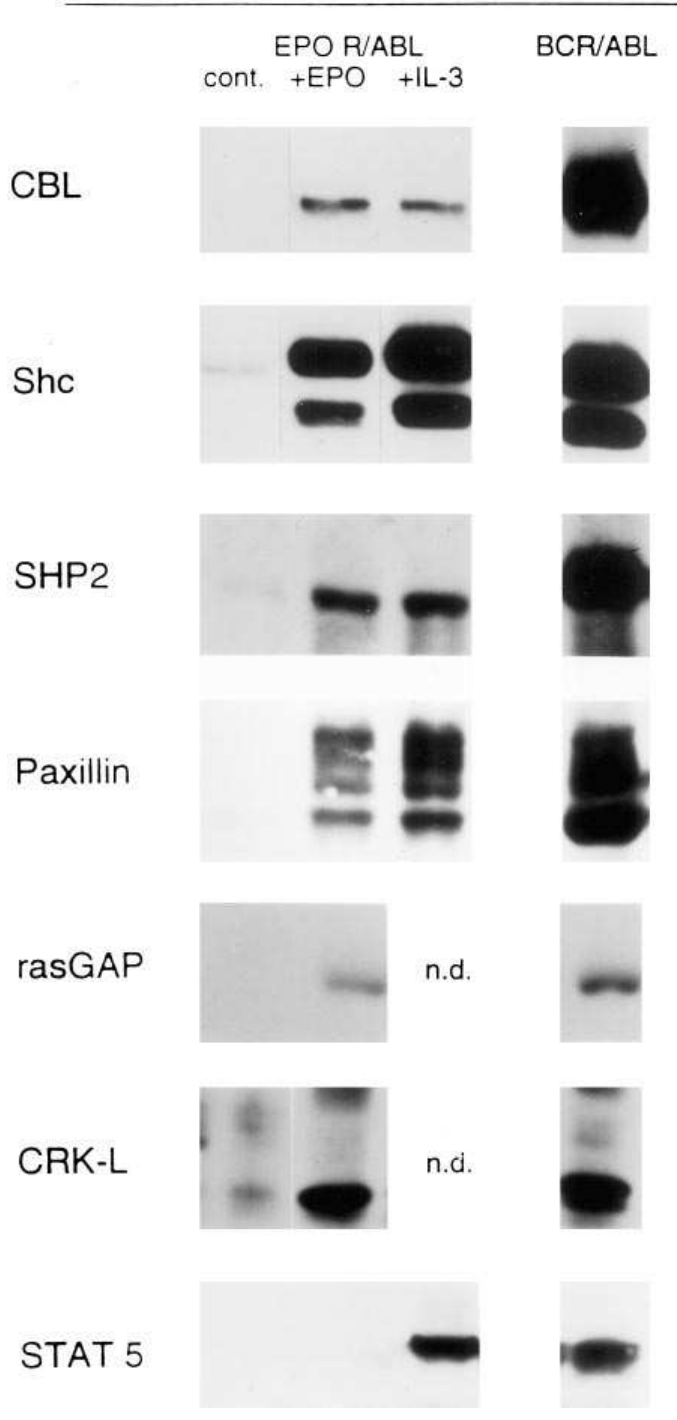

Figure 4. EPO induces tyrosine phosphorylation of signaling proteins in $\mathrm{Ba} / \mathrm{F} 3$ cells with EPO R/ABL. Ba/F3 EPO R/ABL cells were starved of growth factors overnight, and were then stimulated with medium alone (control), EPO ( $2 \mathrm{U} / \mathrm{ml})$, or IL-3 (1 ng/ml), for $15 \mathrm{~min}$. Cell lysates were immunoprecipitated with antibodies as indicated, followed by antiphosphotyrosine immunoblotting with 4G10. On the right, lysates from $\mathrm{Ba} / \mathrm{F} 3$ cells transformed by $\mathrm{BCR} / \mathrm{ABL}$ were similarly immunoprecipitated and blotted as a positive control. n.d., not done.

did not induce tyrosine phosphorylation of cellular proteins in parental $\mathrm{Ba} / \mathrm{F} 3$ cells not expressing EPO R/ABL. These results indicate that the EPO R/ABL kinase has very low kinase activity in the absence of added EPO, but is rapidly and persistently activated after addition of EPO.

Several proteins that are tyrosine phosphorylated by either p210 or p190 BCR/ABL have been previously identified. Therefore, we asked if activation of the EPO R/ABL kinase resulted in tyrosine phosphorylation of any of the same substrates. To compare the differences in detail, we evaluated the phosphorylation state of individual proteins by immunoprecipitation with antiphosphotyrosine antibody followed by specific
A

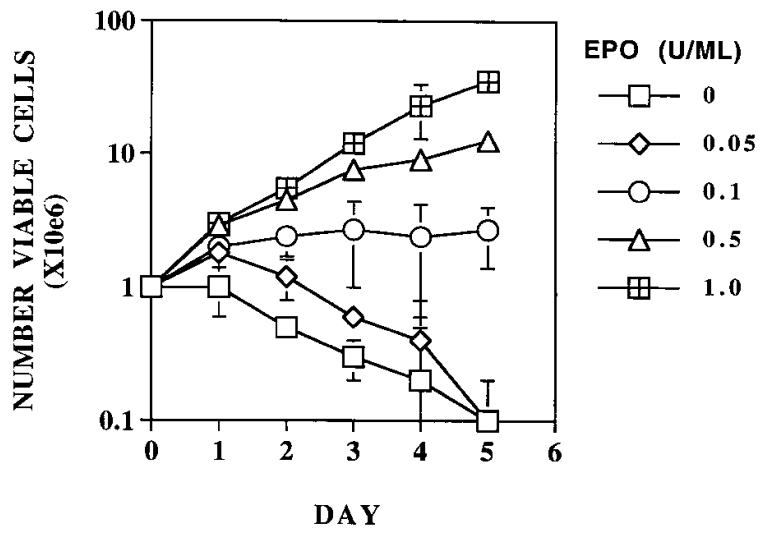

B

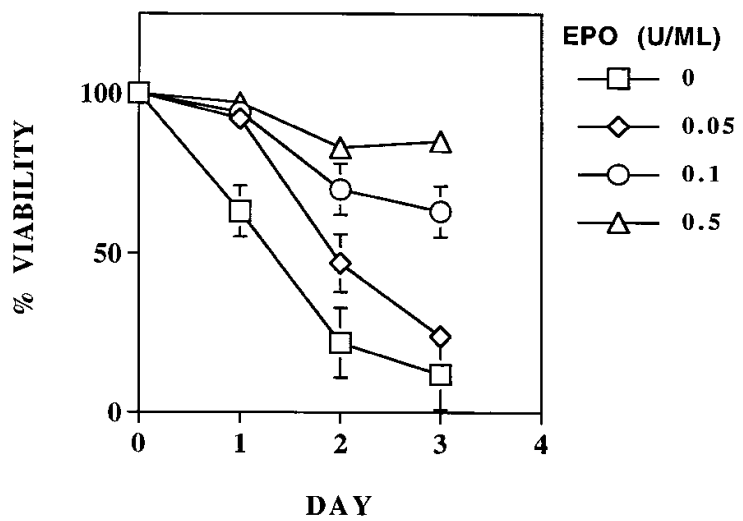

C

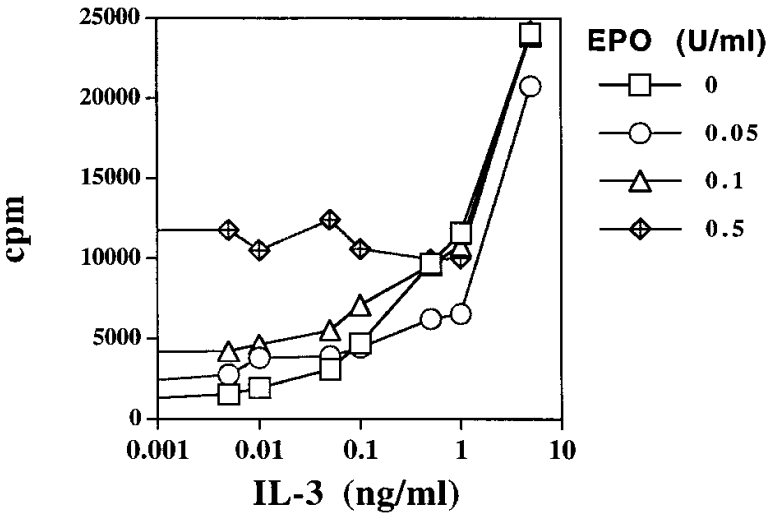

Figure 5. EPO induces a dose-dependent increase in viability and proliferation of $\mathrm{Ba} / \mathrm{F} 3$ cells with $\mathrm{EPO} \mathrm{R} / \mathrm{ABL}$. Cells were washed two times to remove WEHI-conditioned medium, and were then cultured with $0-1.0 \mathrm{U} / \mathrm{ml} \mathrm{EPO}$ as shown, and total number $(A)$ and percentage $(B)$ of viable cells were enumerated using $0.04 \%$ Trypan blue staining. $(C)$ Effect of ABL kinase on IL-3-induced cell proliferation. Triplicate aliquots of $\mathrm{Ba} / \mathrm{F} 3 \mathrm{EPO}$ R/ABL cells were cultured with IL-3 and with $0-0.5 \mathrm{U} / \mathrm{ml} \mathrm{EPO}$ as indicated, for $72 \mathrm{~h}$. Cell proliferation was measured by $\left[{ }^{3} \mathrm{H}\right]$ Thymidine incorporation. Standard error bars are shown in $(A)$ and $(B)$. In $(C)$, all standard errors are $\leq \pm 11 \%$.

antibody blotting. In all cases, the results were confirmed by the reciprocal experiment, i.e., immmunoprecipitaion with substrate-specific antibodies followed by immunoblotting with antiphosphotyrosine antibody. The activated EPO R/ABL protein was found to induce tyrosine phosphorylation of several proteins known to be substrates of $\mathrm{BCR} / \mathrm{ABL}$, including Shc, rasGAP, CBL, Paxillin, SHP2, CRKL, but not STAT 5. 
Besides these tyrosine phosphorylations, EPO also induced serine/threonine phosphorylation of Raf, as indicated by a mobility shift on SDS-polyacrylamide gels, and also induced expression of several early response genes, such as $c-m y c$ and $c$-fos, by greater than 10-fold (Fig. 4 and data not shown).

Activation of the EPO R/ABL tyrosine kinase by EPO enhances viability and induces proliferation in a dose-dependent manner. The biological effects of activating c-ABL kinase in EPO R/ABL Ba/F3 cells were examined. EPO induced a dosedependent increase in proliferation of EPO R/ABL cells, but had no effect on control Ba/F3 cells (Fig. $5 A$ ). At concentrations of EPO below $0.25 \mathrm{U} / \mathrm{ml}$, EPO maintained cell number and viability for several days, but did not cause significant proliferation. In the absence of EPO, EPO R/ABL Ba/F3 cells died at the same rate as did parental $\mathrm{Ba} / \mathrm{F} 3$ cells cultured in the absence of growth factor. In studies not shown, the rate of EPO-induced proliferation of EPO R/ABL Ba/F3 cells was compared to that of $\mathrm{Ba} / \mathrm{F} 3$ cells expressing a wild-type $\mathrm{EPO}$ receptor. The maximum rate of EPO-induced proliferation of EPO R/ABL Ba/F3 cells was 10 -fold less than that observed in $\mathrm{Ba} / \mathrm{F} 3$ cells expressing the same amount of full-length EPO receptors, and also required approximately fourfold more EPO than did $\mathrm{Ba} / \mathrm{F} 3$ cells with wild-type EPO receptor. This difference suggests that the wild-type EPO receptor is more efficient at inducing proliferation than is the EPO R/ABL receptor.

The ability of the EPO R/ABL receptor to directly enhance viability was also examined (Fig. $5 \mathrm{~B}$ ). The parental $\mathrm{Ba} /$ F3 cell line is factor-dependent, and rapidly dies by apoptosis in the absence of IL-3. EPO caused a dose-dependent increase in viability of EPO R/ABL cells, but had no effect on $\mathrm{Ba} / \mathrm{F} 3$ parental cells (Fig. $5 \mathrm{~B}$ and data not shown). In the absence of EPO and IL-3, the EPO R/ABL cells died at the same rate as did the parental $\mathrm{Ba} / \mathrm{F} 3$ cells (data not shown).

$\mathrm{BCR} / \mathrm{ABL}$ has been reported to increase the sensitivity of progenitor cells to hematopoietic growth factors such as IL-3 (27). We tested the effects of activating the EPO R/ABL receptor on the sensitivity of $\mathrm{Ba} / \mathrm{F} 3$ cells to IL-3-induced proliferation. IL-3 dose-response curves were generated in the presence of fixed concentrations of EPO. Although EPO increased baseline proliferation in the absence of IL-3, it did not shift the dose response curve (Fig. $5 \mathrm{C}$ ). These results suggest that activation of $\mathrm{ABL}$ in the context of this chimeric receptor does not result in synergy with the IL-3 receptor. There was, however, an additive effect of EPO R/ABL activation and IL-3 receptor activation (Fig. $5 \mathrm{C}$ ).

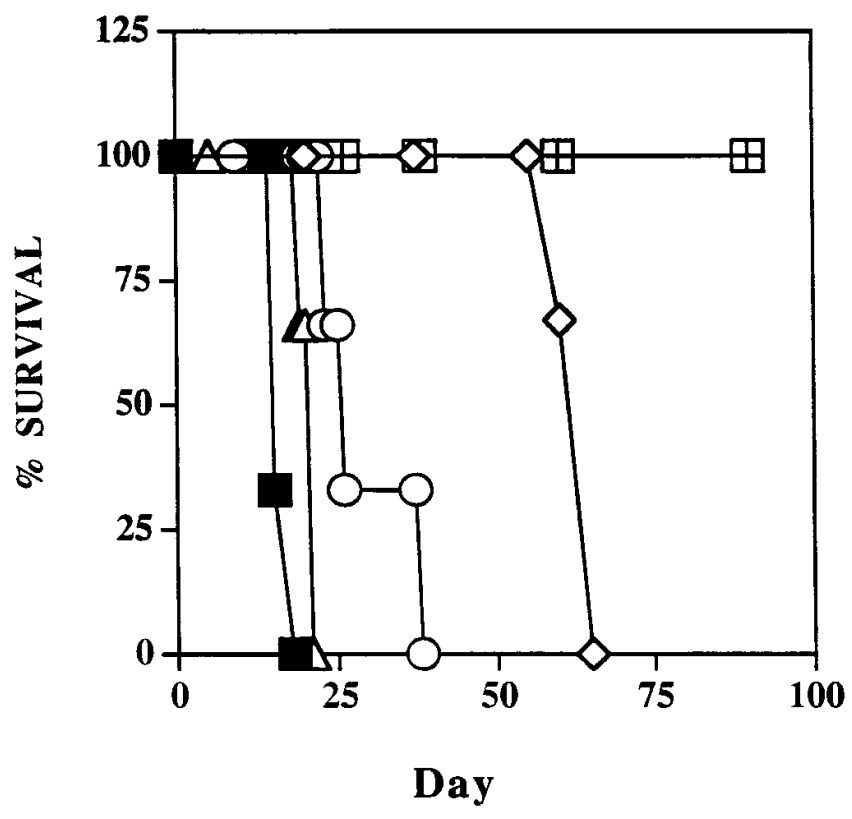

Figure 7. EPO causes a dose-dependent lethal leukemia in nude mice with EPO R/ABL cells. On day 0 , mice received either $1 \times 10^{7} \mathrm{Ba} / \mathrm{F} 3$ parental cells, $1 \times 10^{6} \mathrm{Ba} / \mathrm{F} 3 \mathrm{BCR} / \mathrm{ABL}$ cells or $5 \times 10^{6} \mathrm{Ba} / \mathrm{F} 3 \mathrm{EPO}$ $\mathrm{R} / \mathrm{ABL}$ cells via tail-vain injection, followed by daily injection with either PBS or EPO intraperitoneally. Three to six mice were included in each group, and the experiment was performed twice. The figure shows the results of a single experiment. Comparing all four ordered groups $(0,0.5,5$, and $50 \mathrm{U} / \mathrm{d})$ the $P$ value for a trend toward shorter survival as dose was increased was 0.0002 , using a nonparametric test for trend (51). Filled square, $\mathrm{BCR} / \mathrm{ABL}$; open diamond, EPO R/ABL (0.5 U/d); open circle, EPO R/ABL (5 U/d); open triangle, EPO $\mathrm{R} / \mathrm{ABL}$ (50 U/d); open square, EPO R/ABL (0 U/d).

The EPO R/ABL receptor alters integrin function in $B a / F 3$ cells. We have previously reported that introduction of $\mathrm{BCR} /$ ABL into factor-dependent cell lines results in stimulation of short-term adhesion to fibronectin-coated surfaces, apparently by affecting the function of $\beta 1$ integrins (28). Consistent with this result, EPO stimulation of EPO R/ABL Ba/F3 cells resulted in increased adhesion to fibronectin in a short-term assay (Fig. 6).

Generation of ligand-dependent leukemia in nude mice. We examined the leukemic potential of parental $\mathrm{Ba} / \mathrm{F} 3$ cells,

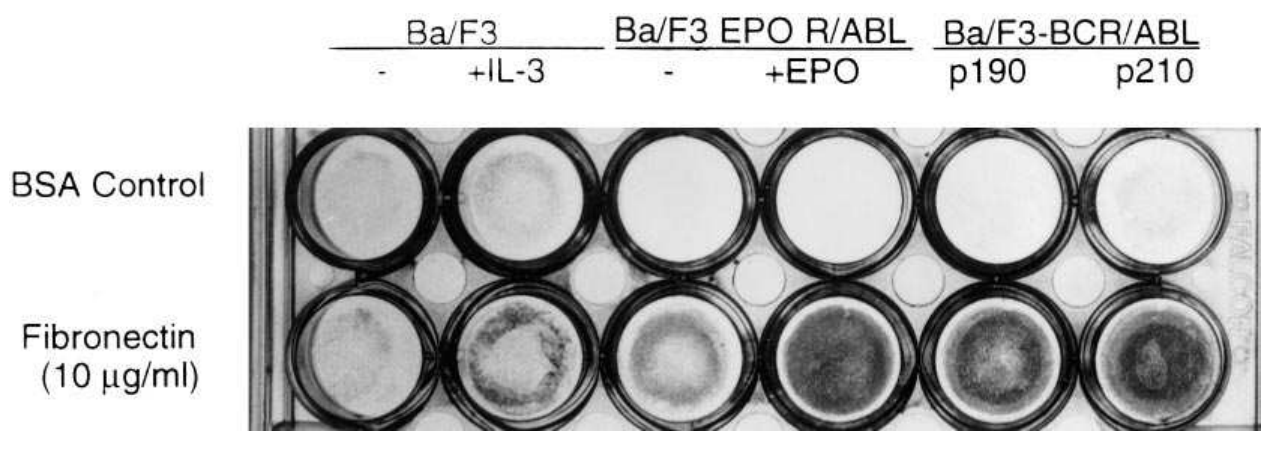

Figure 6. Activation of ABL kinase stimulates adhesion of $\mathrm{Ba} / \mathrm{F} 3$ cells to fibronectin. $\mathrm{Ba} / \mathrm{F} 3$ parental and $\mathrm{Ba} / \mathrm{F} 3 \mathrm{EPO} \mathrm{R} / \mathrm{ABL}$ cells were incubated for $16 \mathrm{~h}$ in the absence or in the presence of either IL-3 $(1 \mathrm{ng} / \mathrm{ml})$ or $\operatorname{EPO}(2 \mathrm{U} / \mathrm{ml})$, and were tested for adhesion to wells previously coated with fibronectin $(10 \mu \mathrm{g} / \mathrm{ml})$. The figure shows a photograph of the plate, with each well stained for adherent cells with Wright-Giemsa stain. Adhesion assays were also carried out for both $\mathrm{p} 190$ - and p210 $\mathrm{BCR} / \mathrm{ABL}$-transfected $\mathrm{Ba} / \mathrm{F} 3$ cell lines. 
$\mathrm{Ba} / \mathrm{F} 3$ p210BCR/ABL, or $\mathrm{Ba} / \mathrm{F} 3 \mathrm{EPO} \mathrm{R} / \mathrm{ABL}$ cells after intravenous injection into nude mice. After injection of cells, groups of three to five mice were then treated with either EPO (0.5-50 U intraperitoneally daily for $5 \mathrm{~d}$ per wk) or PBS. Nude mice receiving parental $\mathrm{Ba} / \mathrm{F} 3$ cells with or without $\mathrm{EPO}$ remained healthy and did not develop any signs of leukemia or tumor growth after an observation period of $90 \mathrm{~d}$ (Fig. 7). Similarly, mice receiving EPO R/ABL Ba/F3 cells and PBS remained healthy and without signs of tumor formation or leukemia over the 90-d period. All mice injected with $\mathrm{Ba} /$ F3p210BCR/ABL cells, however, died before day 16 with massive hepatosplenomegaly, marrow infiltration, and visible leukemic cells on microscopic examination of stained blood smears. The cells infiltrating the spleen and liver were morphologically identical to $\mathrm{Ba} / \mathrm{F} 3$ cells, and were not consistent with erythroblasts. Mice receiving $\mathrm{Ba} / \mathrm{F} 3 \mathrm{EPO} \mathrm{R} / \mathrm{ABL}$ cells plus $50 \mathrm{U} / \mathrm{d}$ EPO died on days 19-21, also with massive hepatosplenomegaly, marrow infiltration, and leukemia; while the group receiving $\mathrm{EPO} \mathrm{R} / \mathrm{ABL} \mathrm{Ba} / \mathrm{F} 3$ cells plus $5 \mathrm{U} /$ day $\mathrm{EPO}$ died on days $23-38$ of leukemia (Fig. 7). Thus, Ba/F3 cells expressing EPO R/ABL receptor were remarkably nonleukemic in the absence of exogenous EPO treatment, but were rapidly lethal in the presence of EPO, and survival depended on the dose of EPO. Nude mice given parental $\mathrm{Ba} / \mathrm{F} 3$ cells plus $50 \mathrm{U} / \mathrm{d}$ of EPO remained healthy over the observation period (Fig. 7), suggesting that the EPO by itself did not cause mortality, although it would have been expected to cause erythrocytosis. In preliminary experiments, nude mice given $\mathrm{Ba} / \mathrm{F} 3$ cells expressing wild-type EPO R and $0.5 \mathrm{U} / \mathrm{d}$ of EPO ultimately developed leukemia, but only after $60 \mathrm{~d}$. These data suggest that activation of ABL may be particularly transforming for this cell line, despite the fact that EPO R/ABL is considerably less mitogenic than is the wild-type EPO receptor in vitro.

\section{Discussion}

Chronic myelogenous leukemia is characterized by massive expansion of myeloid cells and redistribution of myeloid cells from the marrow to the blood and spleen. Interestingly, in contrast to other leukemias of myeloid cells, differentiation is largely normal, and the BCR/ABL oncogene is believed to induce abnormalities of proliferation, adhesion and viability. The increased tyrosine kinase activity of BCR/ABL is essential for transformation $(11,29)$, and requires an $\mathrm{NH}_{2}$-terminal motif in BCR that has been suggested to cause dimerization or oligomerization (10). BCR also has other potentially important sites, including a domain that can bind to the $\mathrm{SH} 2$ domain of $\mathrm{ABL}$, a serine/threonine kinase domain, and a binding site for the SH2 domain of GRB2 that includes tyrosine $177(8,30$ 32). There are three forms of BCR/ABL that are formed by different breakpoints within the $B C R$ gene, each possibly associated with a different type of leukemia (33). Each form contains the oligomerization motif, and it is possible, but not certain, that the differences in the content of BCR in the fusion oncoprotein lead to the distinct clinical diseases (CML vs. ALL).

In this study, we sought to test formally whether oligomerization was sufficient to activate c-ABL tyrosine kinase activity by constructing a chimeric molecule containing the ligandbinding domain of the EPO receptor and c-ABL. The resulting molecule, which functioned as a transmembrane receptor, proved to have EPO-dependent tyrosine kinase activity, phos- phorylated several cytoplasmic proteins, and induced dosedependent increases in viability, adhesion, and proliferation, thus mimicking the biological effects of $\mathrm{BCR} / \mathrm{ABL}$ in this cell line. The EPO R/ABL protein contained a transmembrane domain from the EPO receptor, and was expressed at high levels on the surface of $\mathrm{Ba} / \mathrm{F} 3$ cells when assessed by fluorescence-activated flow cytometry with an antibody to the ligandbinding domain of the EPO receptor. The effects of EPO on tyrosine phosphorylation of cellular proteins was rapid, with increased phosphorylation visible within $5 \mathrm{~min}$. In contrast to the tyrosine phosphorylation induced by normal cytokine receptors, however, the increased phosphorylation was prolonged, and there was no evidence of downregulation for a period of at least $90 \mathrm{~min}$. The prolonged phosphorylation could be due to the fact that endogenous tyrosine phosphatases are not effectively activated by ABL. Alternatively, it is possible that this receptor is not internalized after EPO binding, in contrast to the wild-type EPO receptor.

We compared some of the substrates phosphorylated in $\mathrm{Ba} / \mathrm{F} 3$ cells expressing either the EPO R/ABL or BCR/ABL. The only difference observed was tyrosine phosphorylation of STAT 5 (26) by BCR/ABL, but not by EPO R R/ABL. The biological effects of EPO R/ABL in $\mathrm{Ba} / \mathrm{F} 3$ cells in culture depended on the dose of EPO, with enhanced viability occurring at low doses, and enhanced proliferation and viability at higher doses. In primary patient cells, BCR/ABL has an effect on viability, but does not generally induce factor dependence. When overexpressed in murine marrow or cell lines from either humans or mice, however, BCR/ABL generally induces factor independent proliferation and provides a strong viability signal (34). One explanation for differences in biological effects could be the level of kinase activity in the two situations. In primary cells, ABL tyrosine kinase activity is relatively low, and viability predominates. In cell lines, ABL kinase activity is relatively high after overexpression, and a strong mitogenic signal is revealed. Using another type of inducible BCR/ABL, a temperature-sensitive mutant that can be induced with a temperature change, we have previously shown that low levels of kinase activity also provide primarily a viability signal (35). The results presented here with EPO R/ABL support the hypothesis that there is a difference in the biological effect of an $A B L$ oncogene with low kinase activity (viability) and one with high kinase activity (proliferation). The cell lines described here may be useful to examine signaling pathways that are responsible for both viability and proliferation.

The cell line used here, Ba/F3 cells, has been previously used extensively for evaluating of EPO signaling. It is also of interest to compare signaling of EPO R/ABL with the wildtype EPO R. In Ba/F3 cells, EPO induces prominent, but transient, tyrosine phosphorylation of the EPO receptor, JAK2, STAT 5, SHC, SHP1, SHP2, and p85PI3K (36-43). As noted above, BCR/ABL induces tyrosine phosphorylation of each of these signaling molecules, while EPO R/ABL phosphorylates all except STAT 5. The overlap in signaling of BCR/ABL with growth factor receptors has previously been noted (44).

Another biological effect of activating the EPO R/ABL receptor in $\mathrm{Ba} / \mathrm{F} 3$ cells is a striking change in integrin-mediated adhesion to fibronectin. Abnormalities of integrin function were first reported by Gordon and colleagues, who demonstrated that CML cells had decreased ability to bind to stromal cells from marrow cultures $(45,46)$. Verfaillie et al. described specific defects in $\beta 1$ integrin-mediated binding to fibronectin, 
which interestingly were reversed by exposure to $\alpha$-interferon (47). In murine cell lines such as $\mathrm{Ba} / \mathrm{F} 3$ and $32 \mathrm{Dcl} 3$, we have previously shown that a prominent effect of $\mathrm{BCR} / \mathrm{ABL}$ is to increase short-term adhesion to fibronectin, but longer term adhesion is normal or decreased (28). Recently, using timelapse video microscopy to observe cell shape and motility over time, cells expressing $\mathrm{BCR} / \mathrm{ABL}$ were observed to have multiple abnormalities of cytoskeletal function, including increased spontaneous motility, increased membrane ruffling, and aberrant regulation of the formation of pseudopods and filopodia (48). Taken together, there is accumulating data that BCR/ ABL adversely affects the normal functioning of the cytoskeleton, and that these abnormalities are likely to contribute to the clinical abnormalities in CML. Activation of the EPO $\mathrm{R} / \mathrm{ABL}$ receptor induced a rapid increase in the short-term adhesion of $\mathrm{Ba} / \mathrm{F} 3$ cells to fibronectin, consistent with our earlier studies with BCR/ABL in 32Dcl3 cells (28). This is of interest because these two kinases are likely to be in different cellular compartments, with EPO R/ABL being presumably a transmembrane protein, and $\mathrm{BCR} / \mathrm{ABL}$ a cytoplasmic protein located primarily in the cytoskeleton (49). Because of this difference in location, we specifically looked for phosphorylation of several of the cytoskeleton proteins previously shown to be targets of the $\mathrm{BCR} / \mathrm{ABL}$ kinase, including paxillin and vinculin $(49,50)$. Both of these proteins are limited to focal adhesions within the cytoskeleton, but both were prominently phosphorylated in response to activation of EPO R/ABL. This result suggests that this chimeric receptor has access to cytoskeletal proteins, despite its transmembrane location. The actin-binding domain of ABL (12) is intact in this chimeric molecule, and it will be of interest to determine if the actin-binding domain is required to link EPO R/ABL to cytoskeletal proteins such as paxillin and vinculin.

The effects of the EPO R/ABL molecule in vivo were tested by injecting $\mathrm{Ba} / \mathrm{F} 3$ cells expressing this receptor intravenously into nude mice. In the absence of administration of daily injections of EPO, the cell line did not cause a detectable leukemia, and the mice remained apparently healthy for $>90 \mathrm{~d}$. EPO administration, however, resulted in accumulation of $\mathrm{Ba} / \mathrm{F} 3$ cells in the spleen, liver, blood, and marrow, and this leukemia was lethal in 15-60 d, depending on the dose of EPO given. The $\mathrm{Ba} / \mathrm{F} 3$ cell line expressing EPO $\mathrm{R} / \mathrm{ABL}$ could be readily recovered from the spleens of animals with EPO-induced leukemia, but not from the spleens of animals receiving the same number of initial EPO R/ABL cells without subsequent EPO injection. Interestingly, the leukemia was at least partially reversible, since ceasing of EPO administration at the time of overt leukemia and massive splenomegaly resulted in rapid decrease in organomegaly, and in prolonged survival. Overall, these results suggest that the EPO R/ABL is not capable of transforming the nonleukemic $\mathrm{Ba} / \mathrm{F} 3$ cells by itself in vivo, but will produce a fulminant leukemia if exogenous EPO is supplied. An interesting question here is why the EPO R/ABL$\mathrm{Ba} / \mathrm{F} 3$ cells require exogenous EPO to generate a leukemia, when the mice are presumably producing enough endogenous EPO in the kidneys to prevent anemia. It is quite possible that the EPO R/ABL has a lower affinity for EPO than does the wild-type EPO receptor. Also, it is possible that non-EPOtreated mice will ultimately develop leukemia over time, and that the endogenous levels of EPO are not enough to support proliferation, but only viability. Finally, it is possible that the kidney, where the concentration of EPO would presumably be the highest, does not present an otherwise supportive microenvironment for the proliferation of $\mathrm{Ba} / \mathrm{F} 3$ cells.

This model has some interesting features that may be useful in better understanding the functions of the BCR/ABL oncogene. First, it will be possible to compare the biological effects of $\mathrm{ABL}$ oncogenes with low and high kinase activity in vivo, and preliminary results suggest that the level of kinase activity may be important. Studies to express this receptor in primary murine bone marrow cells are underway, and in these cells it should be possible to test the hypothesis that low ABL kinase activity will cause a myeloproliferative disease, while high kinase activity will also block differentiation. Second, since the effects of EPO are extremely rapid, the effects of activating $\mathrm{ABL}$ on cell homing, migration, extravasation, and marrow exiting can now be investigated in vivo. For example, in preliminary studies, we have found that mice given $\mathrm{Ba} / \mathrm{F} 3$ cells expressing wild-type EPO receptors also develop a fatal neoplasm when treated with EPO, but the accumulation of cells in different organs is different than that of $\mathrm{Ba} / \mathrm{F} 3$ cells expressing EPO R/ABL receptors. Third, this receptor will facilitate in vitro signaling studies of $\mathrm{c}-\mathrm{ABL}$ and $\mathrm{BCR} / \mathrm{ABL}$. Most signaling studies are conducted by adding a growth factor to factor-deprived cells. In fact, many signaling events are difficult to detect, except transiently, after receptor activation. This detection has not previously been possible with oncogenes, and it is possible that new signaling events will be observed as the ABL kinase is rapidly turned on and off. Finally, this construct demonstrates a simple method for activating oncogenes in a reversible manner in vitro and in vivo. By using the EPO receptor, this technique can be readily applied to in vivo situations, facilitated by the facts that EPO is nontoxic to animals, nonimmunogenic, readily administered, and has a short halflife. The ability of the EPO receptor to activate an intracellular protein kinase is of interest, and suggests that this technique might have uses in activating other cytoplasmic kinases, phosphatases, and other signaling molecules.

\section{Acknowledgments}

The authors would like to thank Dr. Donna Neuberg, Department of Biostatistics, Dana-Farber Cancer Institute, for statistical analysis.

This work was supported by National Institutes of Health grants CA66996 and DK560654.

\section{References}

1. de Klein, A., A.G. van Kessel, G. Grosveld, C.R. Bartram, A. Hagemeijer, D. Bootsma, N.K. Spurr, N. Heisterkamp, J. Groffen, and J.R. Stephenson. 1982. A cellular oncogene is translocated to the Philadelphia chromosome in chronic myelocytic leukaemia. Nature (Lond.). 300(5894):765-767.

2. Gabert, J., I. Thuret, Y. Carcassonne, D. Maraninchi, and P. Mannoni. 1990. Residual bcr/abl transcripts in chronic myeloid leukaemia [letter, comment]. Lancet. 335(8686):417-418.

3. Groffen, J., J.R. Stephenson, N. Heisterkamp, A. de Klein, C.R. Bartram, and G. Grosveld. 1984. Philadelphia chromosomal breakpoints are clustered within a limited region, bcr, on chromosome 22. Cell. 36(1):93-99.

4. Heisterkamp, N., K. Stam, J. Groffen, A. de Klein, and G. Grosveld. 1985. Structural organization of the bcr gene and its role in the Ph' translocation. Nature (Lond.). 315(6022):758-761.

5. Heisterkamp, N., E. Knoppel, and J. Groffen. 1988. The first BCR gene intron contains breakpoints in Philadelphia chromosome positive leukemia. Nucleic Acids Res. 16(21):10069-10081.

6. Shtivelman, E., B. Lifshitz, R.P. Gale, and E. Canaani. 1985. Fused transcript of abl and ber genes in chronic myelogenous leukaemia. Nature (Lond.). 315(6020):550-554.

7. Stam, K., N. Heisterkamp, G. Grosveld, A. de Klein, R.S. Verma, M. Coleman, H. Dosik, and J. Groffen. 1985. Evidence of a new chimeric bcr/c-abl mRNA in patients with chronic myelocytic leukemia and the Philadelphia chro- 
mosome. N. Engl. J. Med. 313(23):1429-1433.

8. Pendergast, A.M., A.J. Muller, M.H. Havlik, Y. Maru, and O.N. Witte. 1991. BCR sequences essential for transformation by the BCR-ABL oncogene bind to the ABL $\mathrm{SH} 2$ regulatory domain in a non-phosphotyrosine-dependent manner. Cell. 66(1):161-171.

9. McWhirter, J.R., and J.Y. Wang. 1991. Activation of tyrosinase kinase and microfilament-binding functions of c-abl by bcr sequences in bcr/abl fusion proteins. Mol. Cell. Biol. 11(3):1553-1563.

10. McWhirter, J.R., D.L. Galasso, and J.Y. Wang. 1993. A coiled-coil oligomerization domain of Bcr is essential for the transforming function of BcrAbl oncoproteins. Mol. Cell. Biol. 13(12):7587-7595.

11. Lugo, T.G., A.M. Pendergast, A.J. Muller, and O.N. Witte. 1990. Tyrosine kinase activity and transformation potency of bcr-abl oncogene products. Science (Wash. DC). 247(4946):1079-1082.

12. Van Etten, R.A., P.K. Jackson, D. Baltimore, M.C. Sanders, P.T. Matsudaira, and P.A. Janmey. 1994. The COOH terminus of the c-Abl tyrosine kinase contains distinct F- and G-actin binding domains with bundling activity. $J$. Cell Biol. 124(3):325-340.

13. Papadopoulos, P., S.A. Ridge, C.A. Boucher, C. Stocking, and L.M. Wiedemann. 1995. The novel activation of ABL by fusion to an ets-related gene, TEL. Cancer Res. 55(1):34-38.

14. Golub, T.R., G.F. Barker, S.K. Bohlander, S.W. Hiebert, D.C. Ward, P. Bray-Ward, E. Morgan, S.C. Raimondi, J.D. Rowley, and D.G. Gilliland. 1995. Fusion of the TEL gene on 12p13 to the AML1 gene on 21q22 in acute lymphoblastic leukemia. Proc. Natl. Acad. Sci. USA. 92(11):4917-4921.

15. Golub, T.R., A. Goga, G.F. Barker, D.E. Afar, J. McLaughlin, S.K. Bohlander, J.D. Rowley, O.N. Witte, and D.G. Gilliland. 1996. Oligomerization of the ABL tyrosine kinase by the Ets protein TEL in human leukemia. Mol. Cell. Biol. 16(8):4107-4116.

16. Okuda, K., T.R. Golub, D.G. Gilliland, and J.D. Griffin. 1996. p210BCR/ABL, p190BCR/ABL, and TEL/ABL activate similar signal transduction pathways in hematopoietic cell lines. Oncogene. 13:1147-1152

17. Watowich, S.S., D.J. Hilton, and H.F. Lodish. 1994. Activation and inhibition of erythropoietin receptor function: Role of receptor dimerization. Mol. Cell. Biol. 14:3535-3549.

18. Andoniou, C.E., C.B. Thien, and W.Y. Langdon. 1994. Tumour induction by activated abl involves tyrosine phosphorylation of the product of the cbl oncogene. EMBO (Eur. Mol. Biol. Organ.) J. 13(19):4515-4523.

19. Matsuguchi, T., R. Salgia, M. Hallek, M. Eder, B. Druker, T. Ernst, and J.D. Griffin. 1994. Shc phosphorylation in myeloid cells is regulated by GMCSF, IL-3, and Steel Factor, and is constitutively increased by p210BCR/ABL. J. Biol. Chem. 269:5016-5021.

20. Sattler, M., R. Salgia, K Okuda, N. Uemura, M. A. Durstin, E. Pisick, G. Xu, J.L. Li, K.V. Prasad, and J.D. Griffin. 1996. The proto-oncogene product p120CBL and the adaptor proteins CRKL and c-CRK link c-ABL, p190BCR/ $\mathrm{ABL}$ and $\mathrm{p} 210 \mathrm{BCR} / \mathrm{ABL}$ to the phosphatidylinositol-3' kinase pathway. Oncogene. 12(4):839-846.

21. D'Andrea, A.D., H.F. Lodish, and G.G. Wong. 1989. Expression cloning of the murine erythropoietin receptor. Cell. 57:277-285.

22. Ben-Neriah, Y., A. Bernards, G. Paskind, G.Q. Daley, and D. Baltimore. 1986. Alternative 5' exons in c-abl mRNA. Cell. 44:577-586.

23. D'Andrea, A.D., A. Yoshimura, H. Youssoufian, L.I. Zon, J.W. Koo, and H.F. Lodish. 1991. The cytoplasmic region of the erythropoietin receptor contains nonoverlapping positive and negative growth-regulatory domains. Mol. Cell. Biol. 11:1980-1987.

24. Barber, D.E., J.C. DeMartino, M.O. Showers, and A.D. D'Andrea. 1994. A dominant negative erythropoietin(EPO) receptor inhibits EPO-dependent growth and blocks F-gp55-dependent transformation. Mol. Cell. Biol. 14: 2257-2265.

25. Druker, B., K. Okuda, U. Matulonis, R. Salgia, T. Roberts, and J.D. Griffin. 1992. Tyrosine phosphorylation of rasGAP and associated proteins in chronic myelogenous leukemia cell lines. Blood. 79:2215-2220.

26. Carlesso, N., D.A. Frank, and J.D. Griffin. 1996. Tyrosyl phosphorylation and DNA binding activity of signal transducers and activators of transcription (STAT) proteins in hematopoietic cell lines transformed by Bcr/Abl. $J$. Exp. Med. 183(3):811-820.

27. Gishizky, M.L., and O.N. Witte. 1992. BCR/ABL enhances growth of multipotent progenitor cells but does not block their differentiation potential in vitro. Curr. Top. Microbiol. Immunol. 182:65-72.

28. Bazzoni, G., N. Carlesso, J.D. Griffin, and M.E. Hemler. 1996. Bcr/Abl expression stimulates integrin function in hematopoietic cell lines. J. Clin. Invest. 98(2):521-528.

29. Kelliher, M., A. Knott, J. McLaughlin, O.N. Witte, and N. Rosenberg. 1991. Differences in oncogenic potency but not target cell specificity distinguish the two forms of the BCR/ABL oncogene. Mol. Cell. Biol. 11(9):4710-4716.

30. Maru, Y., and O.N. Witte. 1991. The BCR gene encodes a novel serine/ threonine kinase activity within a single exon. Cell. 67(3):459-468.

31. Muller, A.J., J.C. Young, A.M. Pendergast, M. Pondel, N.R. Landau, D.R. Littman, and O.N. Witte. 1991. BCR first exon sequences specifically activate the $\mathrm{BCR} / \mathrm{ABL}$ tyrosine kinase oncogene of Philadelphia chromosome-positive human leukemias. Mol. Cell. Biol. 11(4):1785-1792.

32. Pendergast, A.M., L.A. Quilliam, L.D. Cripe, C.H. Bassing, Z. Dai, N. Li, A. Batzer, K.M. Rabun, C.J. Der, J. Schlessinger, and M.L. Gishizky. 1993. BCR-ABL-induced oncogenesis is mediated by direct interaction with the SH2 domain of the GRB-2 adaptor protein. Cell. 75(1):175-185.

33. Melo, J.V. 1996. The diversity of BCR-ABL fusion proteins and their relationship to leukemia phenotype [editorial, comment]. Blood. 88(7):23752384 .

34. Daley, G., and D. Baltimore. 1988. Transformation of an interleukin3-dependent hematopoietic cell line by the chronic myelogenous leukemia-specific p210 BCR/ABL protein. Proc. Natl. Acad. Sci. USA. 85:9312.

35. Carlesso, N., J.D. Griffin, and B.J. Druker. 1994. Use of a temperature sensitive mutant to define the biological effects of the p210bcr/abl tyrosine kinase on proliferation of a factor-dependent murine myeloid cell line. Oncogene. 9:149-156.

36. Linnekin, D., G.A. Evans, A. D'Andrea, and W.L. Farrar. 1992. Association of the erythropoietin receptor with protein tyrosine kinase activity. Proc. Natl. Acad. Sci. USA. 89(14):6237-6241.

37. Damen, J., A.L. Mui, P. Hughes, K. Humphries, and G. Krystal. 1992. Erythropoietin-induced tyrosine phosphorylations in a high erythropoietin receptor-expressing lymphoid cell line. Blood. 80(8):1923-1932.

38. D'Andrea, A.D., A. Yoshimura, H. Youssoufian, L.I. Zon, J.W. Koo, and H.F. Lodish. 1991. The cytoplasmic region of the erythropoietin receptor contains nonoverlapping positive and negative growth-regulatory domains. Mol. Cell. Biol. 11(4):1980-1987.

39. Barber, D.L., J.M. Mason, T. Fukazawa, K.A. Reedquist, B.J. Druker, H. Band, and A.D. D'Andrea. 1997. Erythropoietin and interleukin-3 activate tyrosine phosphorylation of CBL and association with CRK adaptor proteins. Blood. 89(9):3166-3174.

40. Matsumoto, A., M. Masuhara, K. Mitsui, M. Yokouchi, M. Ohtsubo, H. Misawa, A. Miyajima, and A. Yoshimura. 1997. CIS, a cytokine inducible SH2 protein, is a target of the JAK-STAT5 pathway and modulates STAT5 activation. Blood. 89(9):3148-3154.

41. Krosl, J., J.E. Damen, G. Krystal, and R.K. Humphries. 1995. Erythropoietin and interleukin-3 induce distinct events in erythropoietin receptorexpressing BA/F3 cells. Blood. 85(1):50-56.

42. Shimizu, R., N. Komatsu, Y. Nakamura, H. Nakauchi, Y. Nakabeppu, and Y. Miura. 1996. Role of c-jun in the inhibition of erythropoietin receptormediated apoptosis. Biochem. Biophys. Res. Commun. 222(1):1-6.

43. Gobert, S., F. Porteu, S. Pallu, O. Muller, M. Sabbah, I. Dusanter-Fourt, G. Courtois, C. Lacombe, S. Gisselbrecht, and P. Mayeux. 1995. Tyrosine phosphorylation of the erythropoietin receptor: role for differentiation and mitogenic signal transduction. Blood. 86(2):598-606.

44. Matulonis, U., R. Salgia, K. Okuda, B. Druker, and J.D. Griffin. 1993. Interleukin-3 and p210 BCR/ABL activate both unique and overlapping pathways of signal transduction in a factor-dependent myeloid cell line. Exp. Hematol. 21(11):1460-1466.

45. Gordon, M.Y., C.R. Dowding, G.P. Riley, J.M. Goldman, and M.F. Greaves. 1987. Altered adhesive interactions with marrow stroma of haematopoietic progenitor cells in chronic myeloid leukaemia. Nature (Lond.) 328(6128):342-344.

46. Gordon, M.Y., C.R. Dowding, G.P. Riley, J.M. Goldman, and M.F. Greaves. 1989. Adhesive defects in chronic myeloid leukemia [review]. Curr. Top. Microbiol. Immunol. 149:151-155.

47. Verfaillie, C.M., J.B. McCarthy, and P.B. McGlave. 1992. Mechanisms underlying abnormal trafficking of malignant progenitors in chronic myelogenous leukemia. J. Clin. Invest. 90:1232-1241.

48. Salgia, R., J.-L. Le, D.S. Ewaniuk, W. Pear, E. Pisick, S.A. Burky, T. Ernst, M. Sattler, L.B. Chen, and J.D. Griffin. 1997. BCR/ABL induces multiple abnormalities of cytoskeletal function. J. Clin. Invest. 100:46-57.

49. Salgia, R., M. Sattler, E. Pisick, J.L. Li, and J.D. Griffin. 1996 p210BCR/ABL induces formation of complexes containing focal adhesion proteins and the protooncogene product p120c-Cbl. Exp. Hematol. 24(2):310-313.

50. Salgia, R., B. Brunkhorst, E. Pisick, J.-L. Li, S.H. Lo, L.B. Chen, and J.D. Griffin. 1995. Increased tyrosine phosphorylation of focal adhesion proteins in myeloid cell lines expressing p210BCR/ABL. Oncogene. 11:1149-1155.

51. Cuzick, J. 1985. A Wilcoxon-type test for trend. Stat. Med. 4:87-90. 